\title{
Democracia e Jurisdição: Aspectos Político-Jurídicos dos Legitimados a Propor Ações de Inconstitucionalidade Junto ao Supremo Tribunal Federal
}

\author{
Democracia y Jurisdicción: Aspectos Políticos-Jurídicos de Los \\ Legitimados a Proponer Acciones de Inconstitucionalidad Junto al \\ Supremo Tribunal Federal
}
Democracy and Jurisdiction: Political and Legal Aspects of Legitimates to Proposals of Unconstitutionality to the Supreme Federal Court

\author{
Anderson Rodrigo Andrade de Lima ${ }^{1}$ \\ Angela Quintanilha Gomes ${ }^{2}$ \\ Íris Gomes dos Santos ${ }^{3}$
}

\begin{abstract}
Resumo
Historicamente a interpretação constitucional é encarada como uma atividade eminentemente técnica, restrita, portanto, aos profissionais do meio jurídico. Esse pensamento limita a noção mais ampla de cidadania, na medida em que exclui a maior parte da sociedade desse processo. A partir da Constituição Federal de 1988 houve a ampliação do rol de legitimados a propor ações de controle concentrado de constitucionalidade, bem como passou-se a admitir uma maior participação de atores externos ao meio jurídico nas referidas ações. $\mathrm{O}$ artigo tem por escopo analisar esse processo de democratização da interpretação jurídica, tema que ganha especial relevo no momento em que o Poder Judiciário firma posição como garantidor das prestações positivas do Estado, como os direitos fundamentais e as políticas públicas.
\end{abstract}

Palavras-Chave: Democracia; Interpretação Constitucional; Controle de Constitucionalidade.

\section{Resumen}

Históricamente la interpretación constitucional es considerada como una actividad eminentemente técnica, restringida, por lo tanto, a los profesionales del medio jurídico. Este pensamiento limita la noción más amplia de ciudadanía, en la medida en que excluye la mayor parte de la sociedad de ese proceso. A partir de la Constitución Federal de 1988 hubo la ampliación del rol de legitimados a proponer acciones de control concentrado de constitucionalidad, así como se pasó a admitir una mayor participación de actores externos al medio jurídico en las referidas acciones. El artículo tiene por objeto analizar ese proceso de democratización de

\footnotetext{
${ }^{1}$ Bacharel em Direito pela Universidade Regional Integrada. Aluno regular do Mestrado de Políticas Públicas da Universidade Federal do Pampa. Servidor público federal; anderson-ral@ hotmail.com.

2 Professora Adjunta da Universidade Federal do Pampa. Bacharelado em Ciência Sociais pela PUC-RS, Mestrado e Doutorado em Ciência Política, pela Universidade Federal do Rio Grande do Sul; angelaqg@terra.com.br.

${ }^{3}$ Graduada em Secretariado Executivo (UFBA), mestre em Ciências Sociais (UFBA), Doutora em Ciência Política (UFMG) e Pós-doutoranda no Programa de pós-graduação em Ciências Sociais (PPGSC-UFBA); iris.ufmg@gmail.com.
} 
la interpretación jurídica, tema que gana especial relieve en el momento en que el Poder Judicial se posiciona como garante de las prestaciones positivas del Estado, como los derechos fundamentales y las políticas públicas.

Palabras claves: Democracia; Interpretación Constitucional; Control de Constitucionalidad.

\begin{abstract}
Historically the constitutional interpretation are considered an eminently technical activity, restricted, therefore, to the professionals of the juridic environment. Such thinking limits the broader notion of citizenship, to the extent that it excludes most of society from this process. From the Federal Constitution of 1988, there was an increase in the cast of legitimates to propose actions of concentrated control of constitutionality, as well as the admission of a greater participation of actors external to the juridic environment in said actions. The purpose of this article is to analyze this process of democratization of juridic interpretation, an issue that is especially relevant at the moment when the Power Judiciary affirms its position as guarantor of the positive benefits of the State, such as fundamental rights and public policies.
\end{abstract}

Keywords: Democracy; Constitutional Interpretation; Control of Constitutionality.

\title{
1 Introdução
}

O presente artigo propõe como objetivo geral abordar os grandes temas da democracia e jurisdição constitucional sob o fulcro do sistema de controle concentrado de constitucionalidade de leis no Brasil. A inter-relação entre os temas é reconhecida e demonstrada no campo teórico, à luz das lições clássicas liberal e igualitária. Contudo, o texto busca apresentar um ponto de vista mais prático e debruça-se a compreender a abertura do rol de legitimados a propor Ações Diretas de Inconstitucionalidade (ADI) pelo art. 103 da Constituição Federal de 1988.

Demonstra-se que as Constituições anteriores (1946, 1967 e 1969) foram uníssonas na tese da legitimidade exclusiva do Procurador-Geral da República para propor ADI's, numa clara demonstração do que Peter Häberle chamou de "sociedade fechada de intérpretes constitucionais". A Carta Cidadã de 1988, no entanto, ampliou significativamente esse rol, admitindo que novos atores participassem como protagonistas do processo de interpretação e conformação constitucional - evoluindo a histórica noção de "sociedade fechada" para uma moderna "sociedade aberta de intérpretes".

Dessa forma, podem ser estabelecidos como objetivos específicos do trabalho: 1) apresentar a evolução histórica de ampliação do rol de legitimados a propor ADI's no Brasil; 2) demonstrar os critérios que orientaram a escolha do constituinte na montagem do rol do art. 103, CF/88; e 3) investigar se os legitimados são efetivamente representativos da sociedade brasileira, ou seja, se de fato pluralizam e democratizam o debate jurídico-constitucional.

Para tanto, o trabalho usa majoritariamente da técnica de pesquisa bibliográfica e da análise de alguns dados estatísticos disponíveis no site do Supremo Tribunal Federal. No 
primeiro tópico retomam-se os principais aspectos relativos à democracia e jurisdição constitucional, dando-se ênfase ao relevante papel político assumido pelo Poder Judiciário a partir de 1988 e o seu déficit de legitimidade quando atua em áreas mais sensíveis, como nas políticas públicas. A seguir o texto apresenta os principais conceitos relativos ao sistema abstrato de controle de constitucionalidade, o qual é apresentado como instrumento de interpretação e conformação constitucional. Por fim, chega-se à efetiva análise do rol estabelecido no art. 103 da $\mathrm{CF} / 88$, focalizando-se nos aspectos político-jurídicos de cada um dos legitimados, onde se busca compreender seus limites e perspectivas à luz da jurisprudência do STF e do quantitativo de ações propostas entre 1989 e 2016.

\section{Democracia e Jurisdição Constitucional}

A democracia encontra-se inserta no sistema do moderno Estado Democrático de Direito, devendo ser objeto de proteção de todas as instituições que o compõe. Sem a pretensão de aprofundarmos esta discussão, pode-se dizer que a democracia inspira ao menos três significados principais: a ideia de um governo composto pela maioria ou pela vontade geral $^{4}$; a noção de igualdade entre os cidadãos; e de que ela fundamenta e defende a noção de liberdade individual. (PAULA, 2014)

Na lição clássica, a relação entre democracia e constitucionalismo possui ao menos duas vertentes interpretativas: a liberal e a igualitária. Para o pensamento liberal há uma aparente contradição entre o reino da política, alimentado pelas paixões e particularismos e o do direito, movido pela razão e lógica. Nesse sentido, o constitucionalismo representaria uma limitação à construção de decisões majoritárias, uma vez que nem todas as opções democraticamente aceitas são constitucionalmente viáveis. (AVRITZER; MARONA, 2014)

Já a vertente do igualitarismo compreende o constitucionalismo como condição de possibilidade da democracia, especialmente no que diz respeito à ampliação do catálogo de direitos fundamentais ocorridos após a Segunda Grande Guerra. Dessa forma, longe de representar uma limitação à democracia, o constitucionalismo é o fundamento moral da ordem jurídica, uma vez que são os freios constitucionais que a reforçam. (AVRITZER; MARONA, 2014)

\footnotetext{
${ }^{4}$ Importante destacar que essa noção de "governo da maioria" é hodiernamente mitigada pelo respeito ao direito das minorias. Reduzir o conceito de democracia ao quantitativo de votos e/ou aprovação popular, seria o mesmo que admitir que a Alemanha Nazista foi democrática, haja vista que em determinados momentos o Governo Hitler contou com altos índices de aprovação.
} 
No Brasil, a jurisdição constitucional tem ganhado um espaço cada vez maior no debate político. O Poder judiciário ganhou relevado papel na proteção dos direitos e garantias fundamentais, gerando, por via reflexa, a judicialização de inúmeras questões de cunho não propriamente jurídico, como acesso à saúde pública, direito à educação, questões previdenciárias, assistenciais, etc.

Isso decorre, entre outros aspectos, da complexidade do texto constitucional de 1988, que se expandiu pelos mais diversos temas, fazendo com que praticamente todos os assuntos fossem, ao menos, pincelados pela Constituição. A Carta de 1988 é marcadamente prolixa, uma vez que possui 250 artigos em seu texto principal e mais 114 no Ato das Disposições Constitucionais Transitórias. Duas consequências imediatas advindas dessa característica são a necessidade de constantes alterações formais do texto e as diversas interpretações - e aparentes contradições - que o mesmo admite.

$\mathrm{O}$ processo de alteração constitucional segue um rito mais solene, dificultoso e burocrático que o empregado na criação e alteração de leis infraconstitucionais. O tema é tratado pelo art. 60 da Lei Fundamental e estabelece, em síntese, a necessidade de votação em dois turnos com quórum mínimo de dois terços dos Membros de cada Casa do Congresso Nacional para a aprovação de Emendas à Constituição. O protagonista deste processo é, portanto, o Poder Legislativo, uma vez que os poderes Executivo e Judiciário sequer têm participação formal no mesmo.

Já no que diz respeito à interpretação constitucional tem-se por protagonista o Poder Judiciário. No Brasil qualquer juiz ou tribunal pode interpretar a Constituição de forma individualizada, admitindo-se, inclusive, por meio do controle incidental, a declaração de inconstitucionalidade de norma legal que contrarie o texto da Lei Maior. No entanto, a interpretação definitiva da constituição ficou resguardada ao Supremo Tribunal Federal, que atua como seu guardião. ${ }^{5}$ Nesse ponto, Mendes (et al, 2000) destaca que a interpretatividade do Supremo é ilimitada; primeiramente porque está a cargo de uma Corte que se encontra situada fora e acima dos três poderes estatais constituídos (Executivo, Legislativo e Judiciário), e segundo porque ela se desenvolve quase que exclusivamente sobre enunciados abertos, indeterminados e polissêmicos.

Essa primazia do Poder Judiciário na interpretação da constituição não pode, no entanto, ser confundida com exclusividade. Destarte, se o papel principal do Poder Judiciário

\footnotetext{
${ }^{5}$ Assevera o art. 102, I, a da CF/88, que "Compete ao Supremo Tribunal Federal, precipuamente, a guarda da Constituição, cabendo-lhe: I - processar e julgar, originariamente: a) a ação direta de inconstitucionalidade de lei ou ato normativo federal ou estadual e a ação declaratória de constitucionalidade de lei ou ato normativo federal'.
} 
é a conformação do texto constitucional à vida social; e se tal tarefa é desenvolvida através do processo hermenêutico-interpretativo, mister reconhecer a necessidade de que esse processo seja o mais plural e democrático possível.

Nesse sentido, diz-se que o processo evolutivo da democracia impõe que a soberania popular passe do aspecto meramente formal para o material, como se depreende da noção de democracia participativa (JUCA, 2007). No âmbito político a participação popular ocorre de forma direta a partir da escolha dos representantes em âmbito federal, estadual e municipal; além disso, diversos outros instrumentos, como os orçamentos participativos e conselhos populares, têm possibilitado a maior participação do povo na gestão e fiscalização da coisa pública.

A questão se torna mais complexa quando a necessidade de pluralizar e democratizar o debate ascende para o meio jurídico, onde o argumento técnico tende a prevalecer sobre o político. Esse tecnicismo, próprio da ciência jurídica, costuma isolar o debate entre os profissionais da área - advogados, juízes, membros do Ministério Público e doutrinadores reconhecidos. Apesar da relevância dos aspectos técnicos na interpretação jurídica, inegável que esse insulamento entre operadores do direito redunda num considerável déficit democrático.

Destaca-se que no Brasil todos os cargos de primeiro grau do Poder Judiciário são ocupados por agentes aprovados em concursos públicos de provas e títulos. A partir do segundo grau de jurisdição (os tribunais em geral) essa regra é flexibilizada pelo chamado Quinto Constitucional, onde se admite o ingresso de advogados com mais de dez anos dez na composição das cortes, que segue majoritariamente ocupada por juízes de carreira. Já os tribunais superiores ${ }^{6}$ são formados exclusivamente a partir de indicações políticas, naquilo que se tem chamado de "legitimidade emprestada", uma vez que os detentores da legitimidade popular (políticos) a emprestam aos mais altos cargos da jurisdição pátria.

Cruz (2004), tratando sobre o déficit de legitimidade aponta que "o problema central do constitucionalismo atual envolve a questão da legitimidade do exercício coativo do poder". Aponta o autor, que após vários paradigmas já superados, essa é a questão central do direito constitucional contemporâneo. Um dos principais desafios inseridos nesse contexto diz

\footnotetext{
${ }^{6}$ Os quatro tribunais superiores - Tribunal Superior Eleitoral (TSE); Superior Tribunal de Justiça (STJ); Superior Tribunal Militar (STM) e Tribunal Superior do Trabalho (TST) - possuem regras próprias de ocupação dos cargos, que favorecem os membros dos tribunais de segundo grau. Já o Supremo Tribunal Federal, que não é considerado tribunal superior pois encontra-se acima destes, não possui nenhuma regra específica de indicação, bastando tratar-se de brasileiro com mais de 35 anos, notório saber jurídico e reputação ilibada.
} 
respeito ao círculos de atores que participam do processo de conformação da norma à realidade social. Como é cediço, juízes, promotores e demais operadores do direito desempenham suas funções a partir da demonstração de conhecimento técnico, não são, portanto, chancelados pelo voto ou vontade popular.

Um dos autores que mais aprofunda o debate acerca da democratização da interpretação jurídica, e, especialmente a constitucional, é Peter Häberle, para quem este processo sempre esteve muito ligado a dois aspectos: os seus objetivos e tarefas e a metodologia a ser empregada. O autor alemão, contudo, se dispõe a apresentar um novo problema a ser enfrentado acerca do tema: os participantes do processo de interpretação (1997, p.11). Entende ele que a interpretação constitucional vincula-se a uma "sociedade fechada" com um rol isolado de intérpretes - em regra os juízes - de maneira que os métodos usados são excessivamente formais e pouco concretizadores da realidade social (1997, p. 12).

Em se considerando que a constituição representa a "força normativa da vontade política de uma comunidade histórica e, por consequência, a fonte real de validade de todo o sistema normativo" (CITTADINO, 2000, p. 31); mostra-se imprudente deixar sua interpretação restrita a um grupo de técnicos, que nem sempre conhecem ou se preocupam com a realidade social. A superação do paradigma da "sociedade fechada" para uma "sociedade aberta" de intérpretes da Constituição mostra-se essencial, uma vez que além de incluir novos atores políticos no processo, supera-se, em parte, o déficit de legitimidade dos membros do Poder Judiciário.

Häberle sustenta que "todo aquele que vive no contexto regulado por uma norma e que vive com este contexto é, indireta ou, até mesmo diretamente, um intérprete dessa norma" (1997, p. 15). Neste ponto, sua obra é totalmente inovadora, pois altera por completo o "problema" da hermenêutica, que sai da mera questão relacionada à metodologia e objetivos, passando a focar no rol de legitimados a exercê-la. A questão central da hermenêutica constitucional, para o autor, reside em alargar o círculo de participantes do processo interpretativo, buscando um resultado mais adequado à realidade daqueles que vivem sob o seu manto jurídico.

Mas quem seriam esses novos intérpretes? O próprio autor estabelece um rol inicial, que classifica como provisório, uma vez que irá variar de acordo com as nuances e os novos contornos sociais ${ }^{7}$. Apesar da abstratividade do rol de participantes apresentado por Häberle,

\footnotetext{
${ }^{7} \mathrm{O}$ rol de intérpretes citado por Häberle inclui: $1^{\circ}$ ) as funções públicas, nas quais se inserem as decisões vinculantes da Corte Constitucional e os órgãos estatais com poder de decisão vinculante (Executivo e Legislativo). $2^{\circ}$ ) os participantes do processo decisório que não sejam necessariamente órgãos estatais,
} 
fica claro que o processo de interpretação constitucional não pode ficar vinculado apenas às partes interessadas, tampouco ser de participação exclusiva dos operadores do direito (LIMA; ODORISSI; 2015). Noutro giro, é evidente que a organização procedimental exigirá o estabelecimento de limites formais de participantes, de maneira que se respeite a diversidade sociocultural do país sem tornar o processo interpretativo um emaranhado interminável de atores, ações e recursos constitucionais.

\section{O controle de constitucionalidade no Brasil como instrumento da interpretação e conformação das leis à ordem constitucional}

Controle de constitucionalidade é a técnica pela qual o Poder Judiciário verifica, sempre que provocado, a compatibilidade das normas infra legais ao ordenamento jurídico em sua plenitude. O sistema de controle consagra a estrutura hierarquizada do direito positivo, reservando-se à Constituição o topo da pirâmide normativa. Isso impede que as normas infraconstitucionais lhe contrariarem formal ou materialmente.

O primeiro sistema de controle de constitucionalidade surgiu nos Estados Unidos, mais especificamente no ano de 1803, quando a Corte Suprema julgou o famoso caso Marbury Vs Madson. ${ }^{8}$ À época o juiz John Marshal, em decisão inovadora, decidiu pela inaplicabilidade de uma lei federal, por considerá-la incompatível com a Constituição Americana. Em que pese a existência de inúmeras críticas acerca da técnica decisional empregada pelo magistrado, a decisão marca uma clara separação entre os poderes, no qual o Judiciário passa a atuar como autêntico intérprete (e limitador da interpretação) constitucional.

Esse modelo de controle difuso (ou incidental) ingressou na Constituição Brasileira de 1891, sendo regulamentado pela Lei $\mathrm{n}^{\circ} 221$ de 1984. Nele qualquer juiz ou tribunal pode afastar a aplicação de lei que contrarie a Constituição, contudo a decisão somente alcança as partes interessadas. Ou seja, a decisão em sede de controle incidental não afastará a aplicação da lei em abstrato, mas tão somente para quem a busca judicialmente.

exemplificando: o requerente, o requerido, autor, réu, os pareceristas ou experts, além de peritos e outros interessados. $3^{\circ}$ ) a opinião pública democrática e plural, neste item o autor inclui a sociedade de forma generalizada, destacando os jornalistas, partidos políticos, mídia e seus respectivos leitores e telespectadores, associações, igrejas, escolas, etc. $4^{\circ}$ ) a doutrina constitucional, que seria a responsável por tematizar a participação das outras forças, além de participar ativamente com aspectos técnicos sobre os temas (HÄBERLE, 1997, Apud LIMA; ODORISSI, 2015, p. 12)

8 Para maiores detalhes sobre o Caso Marbury Vs Madson acessar: <https://www2.senado.leg.br/bdsf/bitstream/handle/id/93276/Macie1\%20Adhemar.pdf?sequence=1> Acesso em $30 / 06 / 2017$ 
Em 1920, a Constituição Austríaca criou, de forma inédita, uma Corte Constitucional, cuja função precípua era o controle de atos normativos inferiores, tarefa esta que desenvolveria com exclusividade. Ao contrário do sistema americano, o austríaco não se destinava a solução de casos concretos, em que o poder judiciário afasta a incidência de uma norma considerada inconstitucional; neste, o Tribunal Constitucional exclui a norma em abstrato do sistema. Significa dizer que a decisão da Corte não se dirige ao autor da ação e sim ao próprio sistema jurídico.

Esse modelo idealizado por Hans Kelsen ficou conhecido como concentrado, uma vez que sua execução fica restrita (concentrada) a um único órgão decisional. No Brasil, o modelo concentrado foi incluído na Constituição de 1946 pela Emenda no 16 de 1965, atribuindo-se, desde então, ao Supremo Tribunal Federal o julgamento de representações de inconstitucionalidades de leis federais ou estaduais, apresentadas pelo Procurador-Geral da República.

No sistema concentrado busca-se submeter à Corte Constitucional normas cuja constitucionalidade seja duvidosa, independentemente dos interesses individuais que possam existir. Em razão disso, a decisão não terá efeitos diretos apenas para o autor, ao contrário, o resultado do julgamento promoverá a alteração abstrata do sistema jurídico, visando adequálo à melhor conformidade com os preceitos constitucionais. Na Constituição Federal de 1988 o controle concentrado encontra-se distribuído em cinco espécies de ações processuais: a ação direta de inconstitucionalidade (art. 102, I, a); a ação de inconstitucionalidade interventiva (art. 36, III); a ação direta de inconstitucionalidade por omissão (art. 103, §2º ; a ação declaratória de constitucionalidade (art. 102, I, a in fine $\mathrm{EC} \mathrm{n}^{\circ}$ 03/93) e a arguição de

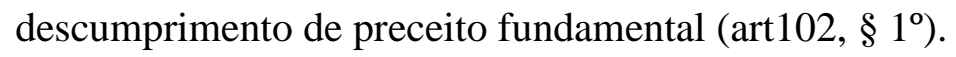

Em todas essas ações existe uma limitação do polo ativo, ou seja, uma restrição sobre quais os legitimados a propô-las. Esse é outro ponto que distingue de forma bastante clara o modelo difuso, em que qualquer pessoa pode levar uma suposta inconstitucionalidade ao judiciário; do concentrado, em que apenas um grupo de pessoas ou entidades têm essa prerrogativa. Os efeitos resultantes do controle concentrado impõe a necessidade de uma limitação do polo ativo, uma vez que sem isso seria impossível dar conta do número de ações que desaguariam no Poder Judiciário. Ao invés de trazer maior justeza e conformidade constitucional, o sistema de controle abstrato sem a limitação dos legitimados resultaria em constante insegurança jurídica, sem falar da impensável sobrecarga de trabalho a que se submeteria a Corte Constitucional. 
Essa legitimidade tradicionalmente fora reservada exclusivamente ao ProcuradorGeral da República (PGR). Tal fórmula foi adotada na Constituição Federal de 1946, através da EC nº 16 de 1965; na Constituição Federal de 1967 e na Emenda à Constituição nº 1 de 19699:

CF/1946 - Art 101 - Ao Supremo Tribunal Federal compete: I - processar e julgar originariamente: k) a representação contra inconstitucionalidade de lei ou ato de natureza normativa, federal ou estadual, encaminhada pelo Procurador-Geral da República; (Redação dada pela Emenda Constitucional $\mathrm{n}^{\circ} 16$, de 1965) (BRASIL 1946)

CF/1967 - Art. 113 - O Supremo Tribunal Federal, com sede na Capital da União e jurisdição em todo o território nacional, compõe-se de 11 (onze) Ministros. 1) a representação do Procurador - Geral da República, por inconstitucionalidade de lei ou ato normativo federal ou estadual; (BRASIL, 1967)

EC No1/1969 - Art. 119. Compete ao Supremo Tribunal Federal: I - processar e julgar originàriamente; l) a representação do Procurador-Geral da República, por inconstitucionalidade de lei ou ato normativo federal ou estadual; (BRASIL, 1969)

A delimitação do polo ativo em apenas um ator, além de restringir substancialmente a participação popular no processo de interpretação constitucional - sendo um perfeito exemplo daquilo que Häberle chamou de "sociedade fechada de intérpretes"; fortalecia, ainda, o chefe do Poder Executivo, uma vez que este era o responsável pelo nomeação dos ProcuradoresGerais da República. O critério de escolha do PGR entre as constituições de 1946 a 1969 era eminentemente político (Quadro 1), exigindo-se tão somente a aprovação formal do Senado em votação aberta, onde sabidamente os parlamentares têm menor grau de liberdade de escolha. Ademais, a EC no 1 de 1969 sequer previu a aprovação pela Câmara Alta, radicalizando a autoridade do Presidente no processo de escolha.

Quadro 1: critérios e procedimentos de escolha e nomeação do Procurador-Geral da República nas Constituições de 1946 a 1989

\begin{tabular}{|c|c|c|}
\hline Constituição & Critério de Escolha & Procedimento \\
\hline $\mathrm{CF} / 1946$ & $\begin{array}{l}\text { Brasileiros maiores de } 35 \text { anos com } \\
\text { notório saber jurídico e reputação } \\
\text { ilibada (art. 99) }\end{array}$ & $\begin{array}{lccc}\text { Escolha e } & \text { nomeação } & \text { pelo } \\
\text { Presidente da } & \text { República } & \text { após } \\
\text { aprovação em voto aberto } & \text { pelo } \\
\text { Senado Federal (art. 126) } & \end{array}$ \\
\hline $\mathrm{CF} / 1967$ & $\begin{array}{l}\text { Brasileiros maiores de } 35 \text { anos com } \\
\text { notório saber jurídico e reputação } \\
\left.\text { ilibada (art. } 113, \S 1^{\circ}\right)\end{array}$ & $\begin{array}{lrcc}\text { Escolha e } & \text { nomeação } & \text { pelo } \\
\text { Presidente da República } & \text { após } \\
\text { aprovação em voto aberto } & \text { pelo } \\
\text { Senado Federal (art. 138) } & \\
\end{array}$ \\
\hline $\mathrm{CF} / 1969$ & $\begin{array}{l}\text { Brasileiros maiores de } 35 \text { anos com } \\
\text { notório saber jurídico e reputação } \\
\text { ilibada (art. 95) }\end{array}$ & $\begin{array}{l}\text { Escolha e nomeação pelo } \\
\text { Presidente da República (art. 95) }\end{array}$ \\
\hline $\mathrm{CF} / 1988$ & Integrantes da carreira do MPU & nomeação \\
\hline
\end{tabular}

\footnotetext{
${ }^{9}$ Embora trate-se de uma Emenda à Constituição de 1967, dada a profundidade de alterações que trouxe à ordem jurídica e social do país, parte da literatura brasileira considera a EC nº 1/69 uma "nova constituição".
} 
RELACult - Revista Latino-Americana de Estudos em Cultura e Sociedade

\begin{tabular}{|l|l|l|}
\hline maiores de 35 anos. (art. 128, $\left.\S 1^{\circ}\right)$ & $\begin{array}{l}\text { Presidente da República após } \\
\text { aprovação do Senado por voto } \\
\text { secreto (art. 52, III) }\end{array}$ \\
\hline
\end{tabular}

Elaborado pelos autores

A CF/1988 trouxe importantes alterações no processo de escolha do PGR, delimitando-a aos membros da carreira do Ministério Público da União mediante aprovação do Senado Federal, por votação secreta. O novo mecanismo além de retomar a importância do Senado - agora com maior liberdade individual dos parlamentares em razão do voto secreto fortaleceu o caráter técnico e institucional, uma vez que os próprios membros do Ministério Público elaboram a lista tríplice que orientará a escolha presidencial.

Importante destacar que a Constituição apenas determina que o Procurador-Geral seja escolhido entre os membros da carreira com mais de 35 anos, sem fazer qualquer menção à participação dos procuradores nesse processo. Consolidou-se, no entanto, a regra consuetudinária de que a cada novo processo de escolha os membros do Ministério Público Federal elaboram, mediante votação, uma lista com três nomes, a qual é encaminhada à apreciação do chefe do executivo. Mesmo a lista não vinculando a escolha presidencial, desde 2003 o indicado com maior número de votos tem sido o escolhido pelo Presidente da República. $^{10}$

Os avanços da Constituição de 1988 nesse tema não se restringiram à nova processualística de escolha do PGR. De forma inédita previu o constituinte que as ações de controle concentrado de constitucionalidade deveriam ter maior participação de setores estratégicos da sociedade, estabelecendo assim um rol exaustivo de participantes no art. 103 da Carta Cidadã:

Art. 103. Podem propor a ação direta de inconstitucionalidade e a ação declaratória de constitucionalidade: (Redação dada pela Emenda Constitucional $n^{\circ} 45$, de 2004) I - o Presidente da República;

II - a Mesa do Senado Federal;

III - a Mesa da Câmara dos Deputados;

IV a Mesa de Assembléia Legislativa ou da Câmara Legislativa do Distrito

Federal; (Redação dada pela Emenda Constitucional no 45, de 2004)

V o Governador de Estado ou do Distrito Federal; (Redação dada pela Emenda

Constitucional $n^{\circ} 45$, de 2004)

VI - o Procurador-Geral da República;

VII - o Conselho Federal da Ordem dos Advogados do Brasil;

VIII - partido político com representação no Congresso Nacional;

IX - confederação sindical ou entidade de classe de âmbito nacional.

\footnotetext{
${ }^{10}$ Tramita no Senado Federal a PEC no 43/2013, de autoria do Senador Cássio Cunha Lima, que altera o $\S 1^{\circ}$ do art. 128 da Constituição Federal e tem o objetivo de positivar esse mecanismo de escolha, visando trazer maior segurança jurídica com relação a esse processo que atualmente não possui qualquer previsão legal. Lembramos, no entanto, que para a escolha do Procuradores-Gerais de Justiça dos Estados o procedimento de listas já foi positivado pelo art. $128, \S 3^{\circ} \mathrm{da} \mathrm{CF} / 88$.
} 
No tópico seguinte restringiremos nossa análise às Ações Diretas de Inconstitucionalidades (ADI), apontando os principais aspectos político-jurídicos e o espectro de abrangência de cada um dos legitimados constitucionais, buscando compreender seus respectivos limites e perspectivas.

\section{Aspectos político-jurídicos dos legitimados do art. $103 \mathrm{CF} / 88$ : limites e perspectivas de participação no processo de interpretação constitucional}

Neste capítulo abordaremos o espectro de atuação dos legitimados a dar início ao processo de controle de constitucionalidade pela via de ação. Para tanto, a análise dar-se-á em dois momentos. No primeiro serão apresentados aspectos gerais dos legitimados, a classificação entre legitimados universais e interessados, seguido de um quadro com o quantitativo de ações iniciadas por cada um destes entre 1989 e 2016. Em segundo plano serão discutidos os principais aspectos teóricos que envolvem suas respectivas atuações, dando-se ênfase aos limites materiais estabelecidos pela jurisprudência do STF e buscando compreender como esses limites influenciam no maior ou menor número de ações propostas.

As ações diretas de inconstitucionalidade são tratadas pela Constituição de 1988 no art. 102, I, “a”; matéria que foi regulamentada pela Lei $\mathrm{n}^{\circ}$ 9.868/99. Já no texto original da $\mathrm{CF} / 88$ foi estabelecido o rol de legitimados a propor as ações de controle, o qual foi alterado pela Emenda Constitucional no 45/2004 apenas para corrigir a redação dos incisos IV e V, visando sanar a dúvida que pairava sobre a legitimidade do Governador e Câmara Legislativa do Distrito Federal. Materialmente o rol jamais foi modificado, contudo a jurisprudência do Supremo Tribunal Federal vêm dando interpretação restritiva ao art. 103, CF.

Exemplo disso é a divisão dos legitimados em universais e interessados. Para o STF, em se tratando das mesas das assembleias legislativas, dos governadores de estado e das confederações ou entidades de classe, deve haver uma "pertinência temática" entre o objeto da ação e a entidade que a propõe. Cumpre destacar que a Constituição não faz qualquer menção a essa necessidade, a qual justifica-se unicamente por questões de política judiciária. Dessa forma, diz-se que os legitimados a propor ADI dividem-se em dois grupos:

Quadro 2: Divisão dos Legitimados em Universais e Interessados

\begin{tabular}{|l|l|}
\hline Legitimados Universais (ou neutros) & Legitimados Interessados (ou especiais) \\
\hline I - o Presidente da República; & IV a Mesa de Assembléia Legislativa ou da \\
II - a Mesa do Senado Federal; & Câmara Legislativa do Distrito Federal; \\
III - a Mesa da Câmara dos Deputados; & V o Governador de Estado ou do Distrito \\
VI - o Procurador-Geral da República; & Federal; \\
VII - o Conselho Federal da Ordem dos & IX - confederação sindical ou entidade de \\
\hline
\end{tabular}




\begin{tabular}{|l|l|}
\hline $\begin{array}{l}\text { Advogados do Brasil; } \\
\text { VIII - partido político com representação no } \\
\text { Congresso Nacional; }\end{array}$ & classe de âmbito nacional. \\
\hline $\begin{array}{l}\text { As ações podem tratar de qualquer tema e } \\
\text { não possuem limitação de objeto }\end{array}$ & $\begin{array}{l}\text { Somente ações cujo tema e objeto possuam } \\
\text { pertinência temática com o legitimado }\end{array}$ \\
\hline
\end{tabular}

Elaborado pelos autores.

A divisão criada pela jurisprudência do STF foi tratada pelo Parágrafo Único do Art. $2^{\circ}$ da Lei $n^{\circ} 9868 / 99$, que previu a necessidade de pertinência temática; in verbis:

Art. $2^{\circ}$ Podem propor a ação direta de inconstitucionalidade:

(...)

IX - confederação sindical ou entidade de classe de âmbito nacional.

Parágrafo único. As entidades referidas no inciso IX, inclusive as federações sindicais de âmbito nacional, deverão demonstrar que a pretensão por elas deduzida tem pertinência direta com os seus objetivos institucionais." (BRASIL, 1999)

Essa previsão, no entanto, foi vetada pelo Presidente da República, de forma que não ingressou no ordenamento jurídico. Assim, ainda que compreensíveis as razões que fundamentam o entendimento do STF, parece-nos forçoso reconhecer que a Corte criou um filtro temático sem qualquer previsão legal, usurpando função própria do Poder Legislativo e restringindo indevidamente $\mathrm{o}$ acesso a esse valioso instrumento de interpretação constitucional.

Superada essa divisão, passamos a análise dos quantitativos de ações diretas de inconstitucionalidades ingressadas no STF desde 1989 até o dia 04 de dezembro de $2012 .{ }^{11}$

Quadro 3: Quantitativo de ADI's por legitimado

\begin{tabular}{|l|c|c|}
\hline Legitimado & Quantidade & Observação \\
\hline Presidente da República & 11 & $(01)$ \\
\hline Mesa do Senado Federal & 1 & \\
\hline Mesa da Câmara dos Deputados & 2 & \\
\hline Mesa de Assembleia Legislativa ou Câmara Legislativa DF & 52 & $(02)$ \\
\hline Governador de Estado ou Distrito Federal & 1121 & \\
\hline Procurador-Geral da República & 984 & $(03)$ \\
\hline Conselho Federal da Ordem dos Advogados do Brasil & 259 & \\
\hline Partido político com representação no Congresso Nacional & 963 & $(04)$ \\
\hline Confederação Sindical ou entidade de classe nacional & 1743 & $(05)$ \\
\hline Total & 5136 & \\
\hline
\end{tabular}

Elaborado pelos autores.

${ }^{11} \mathrm{O}$ quadro foi elaborado com base no relatório emitido pelo STF no dia 04/12/2016. Cumpre observar que os dados disponíveis no site encontram-se organizados de forma diferente, uma vez que um mesmo legitimado aparece diversas vezes em diferentes grupos de ações propostas. Nesta compilação foram totalizadas o número de ações por legitimado, independente do nome que a titulariza no relatório do STF. Relatório do STF disponível em: <(http://www.stf.jus.br/portal/cms/verTexto.asp?servico=estatistica\&pagina=adi) > Acesso em 30/06/2017 
(01) Não foram incluídas 05 (cinco) ações subscritas pelo Advogado-Geral da União, uma vez que se pacificou o entendimento de que a legitimidade do Presidente da República é restrita.

(02) O total inclui tanto as ações subscritas pelas Mesas Diretoras quanto pelas próprias Assembleias Legislativas dos Estados.

(03) O total inclui 05 (cinco) as ações subscritas pela "Procuradoria-Geral da República", não sendo possível verificar a admissibilidade das mesmas pelo STF.

(04) Não foram incluídas as ADI's subscritas por diretórios municipais e estaduais dos referidos partidos políticos.

(05) Esse total não é representativo apenas das confederações e entidades legitimadas, umas vez que nesse grupo se inclui um extensivo rol de associações, federações, pessoas jurídicas e até mesmo físicas que já ingressaram com ADI's no Supremo Tribunal Federal.

O rol de legitimados a propor ações diretas de inconstitucionalidade é fruto de uma escolha política do constituinte originário, de onde pode-se extrair quatro critérios de escolha: a) critério federativo: os legitimados dos incisos I, II, e III são representantes políticos da União, enquanto os dos incisos IV e $\mathrm{V}$ representam a administração e a população dos Estados e Distrito Federal ${ }^{12}$; b) critério técnico: refere-se aos legitimados do incisos VI e VII, umas vez que se tratam de atores diretamente relacionados ao conhecimento técnico de matérias jurídicas, ainda que com funções sociais diversas; c) critério político-partidário: os partidos políticos (inciso VIII) também foram legitimados a propor as ações de controle, o que visou fortalecer ainda mais o papel destes na reforma democrática de 1988; d) critério pluralista: presente no inciso IX, o qual mostra-se como o mais amplo e democrático instrumento de acesso às ações de controle.

Os três primeiros legitimados citados pelo art. 103 são diretamente envolvidos no processo de reforma das normas federais. Tanto as Casas Legislativas (e seus membros) quanto o Presidente da República possuem legitimidade para dar início ao processo de inovação da ordem jurídica, cabendo às primeiras sua condução e ao segundo sua sanção. Em razão disso, o volume de participação destes legitimados no processo de controle de

\footnotetext{
${ }^{12}$ Como é cediço o federalismo no Brasil é de três níveis (União, Estados e municípios). Contudo, é firme a jurisprudência do STF que este terceiro ente político não é legitimado a propor ações diretas de inconstitucionalidade. Nesse sentido: “(...) os municípios não figuram no rol de entidades legitimadas para a propositura de ação direta de inconstitucionalidade perante esta Corte previsto nos arts. 103 da Constituição e $2^{\circ}$ da Lei 9.868/99. [ADI 4.654, rel. min. Gilmar Mendes, decisão monocrática, j. 28-11-2011, DJE de 2-122011.]
} 
constitucionalidade é mínimo, uma vez que tais poderes já dispõe de outras alternativas que podem ser empregadas no curso do processo. ${ }^{13}$

Outra razão que explica a baixa participação das Mesas do Senado e da Câmara são as divergências político-ideológicas entre seus membros. Como se sabe, as Mesas devem representar, tanto quanto possível, a participação proporcional das representações partidárias ou dos blocos parlamentares com representação na respectiva Casa. Isso praticamente inviabiliza a existência de um consenso em relação a qual tema deva ou não ser levado ao STF. Ademais, por ser a arena decisória por excelência, parece incoerente que mesmo após o longo processo legislativo, passando, inclusive, por comissões que analisam a constitucionalidade do projeto, que tais atores busquem a declaração de inconstitucionalidade junto ao Poder Judiciário. Esse papel, como se verá, na maioria das vezes acaba por ser desempenhado pelos partidos políticos.

Os legitimados dos incisos IV (Mesas das Assembleias Legislativas) e V (Governadores de Estados), como já se apontou, representam o interesse dos EstadosMembros a que pertencem. Ambos têm sua atuação circunscrita ao filtro da pertinência temática, portanto podem arguir a inconstitucionalidade de leis federais e estaduais, desde que comprovem que o objeto da norma tenha relevância para a administração do estado, no caso dos governadores ou para a casa legislativa, no caso das assembleias. Os números demonstram que pouquíssimas foram as ADI's iniciadas pelas Mesas das Assembleias Legislativas entre 1989 e 2016. Isso pode ser explicado tanto em razão das divergências ideológicas entre os membros das mesas, quanto pela maior facilidade do instrumento ser usado pelo Governador do Estado. ${ }^{14}$

Já os governadores de estado fazem amplo uso das Ações Diretas de Inconstitucionalidade. Foram 1121 ADI's propostas entre 1989 e 2016, o que faz deste o segundo legitimado que mais usa do referido instrumento processual. Uma das razões que levam ao alto número de ADI's propostas por governadores é a chamada "guerra fiscal", especialmente após a jurisprudência do STF ter consolidado o entendimento de que a lei contestada pode ter sido sancionado em outro estado-membro. Dessa forma, eventual norma

\footnotetext{
${ }^{13}$ Exemplo desses instrumentos são, no caso do Presidente da República, o veto total ou parcial no projeto de lei; já nas Casas Legislativas as opções são inúmeras, indo desde as barganhas políticas até as possibilidades de obstruções de pauta, que por vezes impedem a continuidade das votações.

${ }^{14}$ A Assembleia que mais vezes ingressou com ADI's no STF foi a de Pernambuco, com 08 ações, seguida de Rio de Janeiro e Espírito Santo com 06 e Paraná com 05 ações.
} 
editada num Estado " $\mathrm{X}$ " que venha a criar óbices às finanças de um Estado "Y" poderá ter sua inconstitucionalidade arguida por este perante a Corte Máxima. ${ }^{15}$

Cumpre observar, ainda, que a opção do constituinte foi clara ao tornar legitimado a pessoa do Governador de Estado ou Distrito Federal. Assim, não pode figurar no polo ativo da ação o Estado (ente político), tampouco o vice-governador ou os assessores jurídicos diretos, como Procurador-Geral de Justiça ou Advogado-Geral do Estado. A legitimidade, conforme se apontou anteriormente, tem o escopo de possibilitar aos governadores uma atuação mais efetiva na defesa dos interesses de seu Estado e sua administração, uma vez que estes não possuem participação ativa no processo legislativo federal nem no dos demais estados.

O Procurador-Geral da República (PGR), como já demonstrado, é o mais tradicional dos legitimados a propor as ações de controle de constitucionalidade. Esse fato tem relação com o papel histórico exercido pelo Ministério Público de "fiscal da lei", que no contexto ora tratado não diz respeito à físcalização do cumprimento da lei, mas sim de sua compatibilidade com a Constituição. Por ser um legitimado universal o PGR pode propor ações contra quaisquer leis federais e estaduais, independente da matéria tratada. Esse amplo espectro de abrangência explica as quase 1000 ações propostas entre 1989 e 2016.

Mesmo quando não atua como proponente da ADI o Procurador-Geral da República é participante obrigatório do processo, uma vez que emite parecer opinativo sobre a constitucionalidade na norma atacada. A amplitude de competências do PGR faz deste um dos mais relevantes atores do processo jurídico no país, o que impõe a necessidade de uma escolha que não seja puramente técnica tampouco puramente política. O método da lista tríplice, empregado nos últimos anos, tem reforçado o caráter técnico e classista da escolha, reduzindo consideravelmente a discricionariedade do Presidente da República.

Da mesma forma que o PGR, o Conselho Federal da Ordem dos Advogados do Brasil é um legitimado universal, adotado pelo constituinte em razão de sua importância política na defesa da ordem democrática e das instituições, mas sobretudo pelo caráter técnico da instituição. Mesmo sendo uma representação classista a atuação da OAB supera as restrições da pertinência temática, considerando-se válidas todas as ações impetradas pelo Conselhos Federal em face de normas federais e estaduais.

\footnotetext{
${ }^{15}$ Nesse sentido, o STF admitiu que o Governador de Goiás ingressasse com ADI contra lei que proibia a comercialização de amianto - sancionada pelo Governador de São Paulo. A pertinência temática decorria do fato daquele Estado possuir as maiores reservas do referido minério. (ADI 2.656, rel. min. Maurício Corrêa, julgamento em 8-5-2003, Plenário, DJ de 1º-8-2003.)
} 
Os partidos políticos, por sua vez, trazem à tona a importância do debate democrático e ideológico mesmo nas ações de controle de constitucionalidade, cuja tendência é pautar-se pela técnica jurídica. Não são todos os partidos que possuem legitimidade para ingressar com ADI's junto ao Supremo, mas somente aqueles com representação no Congresso Nacional ${ }^{16}$. Para ingressar com a ação o partido deve estar representado pelo seu Diretório Nacional, ainda que a norma atacada tenha repercussão restrita a determinado estado ou município. ${ }^{17}$ Essa restrição imposta pelo STF não possui previsão na Constituição, no entanto mostra-se coerente com o caráter nacional que os partidos devem possuir para obter registro. ${ }^{18}$

Os partidos, ao contrário das Mesas da Câmara, do Senado e das Assembleias Legislativas, não possuem grandes divergências de interesses na sua composição, uma vez que os respectivos estatutos já norteiam a linha político-ideológica em que o mesmo se insere. Desse forma, ter-se-ia nos partidos (ao menos em tese) a principal representatividade dos ideais democráticos - os quais foram legitimados a levar até a Corte Suprema eventuais derrotas sofridas nas arenas políticas.

O partido que mais vezes ingressou com ADI's no STF foi o Partido dos Trabalhadores (PT), com 143 ações, seguido do Partido Democrático Trabalhista (PDT) com 140 e do Partido Social Liberal (PSL) com 89 ações. ${ }^{19}$ Há inúmeras discussões possíveis nas ADI's impetradas por partidos, tais como: se as teses apresentadas se coadunam com o perfil ideológico da agremiação; se o fato de compor ou não a base do governo influencia no uso desse instrumento; e até mesmo se é possível traçar uma relação entre a representatividade do partido no Congresso e como patrono das referidas ações. Por obvio não temos a pretensão de destrinchar todos esses questionamentos nesse artigo, mas, por hora, apenas de reiterar a importância da legitimidade atribuída aos partidos políticos nas ações de controle de constitucionalidade.

\footnotetext{
${ }^{16}$ Para ter representação no Congresso Nacional o partido deve possuir ao menos 01 (um) deputado federal ou senador. Essa aferição deve se dar no momento em que a ação é proposta, independe de perda superveniente. Nesse sentido: [ADI 2.618 AgR-AgR, rel. min. Gilmar Mendes, j. 12-8-2004, P, DJ de 31-3-2006.]

${ }^{17}$ [ADI 1.528 QO , rel. min. Ellen Gracie, j. 24-5-2000, P, DJ de 23-8-2002.]

18 Além disso, a restrição da legitimidade aos diretórios nacionais mitiga as divergências entre bancadas de diferentes estados que compõe um mesmo partido, obrigando as agremiações a buscarem um consenso interno mínimo antes de ingressar com uma ADI na Corte Constitucional.

${ }^{19}$ Na sequência estão: PSDB - 69 ações; PC do B - 59 ações; DEM 56 ações; PSB - 41 ações; Solidariedade e PHS - 30 ações (etc)
} 
O último legitimado previsto pela Constituição foram as confederações sindicais e as entidades de classe de âmbito nacional. Por certo trata-se do mais plural dos legitimados, possibilitando-se que organizações destituídas de poder político busquem junto ao STF a declaração de inconstitucionalidade de lei. A noção geral que paira sobre este último inciso do artigo 103 é a da "generalização e profusão das vias de participação dos cidadãos nos provimentos estatais", numa leitura bastante próxima do que Peter Häberle chamou de "sociedade aberta de intérpretes da Constituição" Essa amplitude, conforme já apontamos, foi consideravelmente restringida pela necessidade de demonstração da pertinência temática entre o objeto da ação e os interesses da categoria representada. Em razão disso, a atuação das confederações e entidade de classe restou bastante voltada aos interesses econômicos dos representados.

No Quadro 4, após pesquisa com base no relatório emitido pelo setor de estatística do STF, destacamos as dez entidades de classe mais representativas, ou seja, as que mais vezes ingressaram com ações contestando a constitucionalidade de leis junto ao STF. É bastante expressiva a participação de entidades representativas de servidores públicos - especialmente de carreiras jurídicas e policiais - com número bastante superior às demais. ${ }^{20}$ Complementam o quadro duas grandes confederações patronais, a do comércio (CNC) e da indústria (CNI), cujas atuações voltam-se preponderantemente à construção de ambientes favoráveis às pessoas jurídicas que representam, e, apenas reflexamente, aos trabalhadores dos respectivos setores.

Quadro 4: Entidades de classe mais representativas junto ao STF

\begin{tabular}{|l|c|c|}
\hline Legitimado & Sigla & Quantidade \\
\hline Associação dos Magistrados Brasileiros & AMB & 132 \\
\hline $\begin{array}{l}\text { Confederação Nacional do Comércio de bens, serviços e } \\
\text { turismo }\end{array}$ & CNC & 106 \\
\hline Confederação Nacional da Indústria & CNI & 79 \\
\hline Associação Nacional dos Delegados de Polícia do Brasil & ADEPOL & 66 \\
\hline Confederação dos Servidores Públicos do Brasil & CSPB & 63 \\
\hline Associação Nacional dos Membros do Ministério Público & CONAMP & 50 \\
\hline Associação dos Notários e Registradores do Brasil & ANOREG & 49 \\
\hline Associação Nacional dos Procuradores do Estado & ANAPE & 41 \\
\hline Associação Nacional dos Magistrados Estaduais & ANAMAGES & 36 \\
\hline $\begin{array}{l}\text { Confederação Brasileira dos Trabalhadores Policiais } \\
\text { Civis }\end{array}$ & COBRAPOL & 33 \\
\hline
\end{tabular}

Elaborado pelos autores

\footnotetext{
${ }^{20}$ Das 10 entidades citadas apenas 02 não representam servidores públicos da área jurídico-policial, a CNC e a CNI.
} 
A jurisprudência do STF sobre quais organizações enquadram-se como "entidades de classes" é vasta, destacando-se entre as posições já firmadas pela Corte que: a) os conselhos de fiscalização profissional não possuem legitimidade, dada sua natureza jurídica de autarquias especiais $^{21}$; b) as centrais sindicais também não possuem legitimidade, umas vez que representam interesses gerais de trabalhadores e não de uma categoria específica ${ }^{22}$; c) para se considerar de "âmbito nacional" a entidade deve possuir representação em pelo menos 09 estados da federação ${ }^{23}$; d) a União Nacional dos Estudantes (UNE) não possui legitimidade ativa para ingressar com ações de controle de constitucionalidade, pois apesar de sua importância na história política do pais, não representa categoria profissional, conforme restringiu o constituinte ${ }^{24}$; etc.

Há duas possíveis razões para as entidades representativas do meio jurídico terem maior participação que as demais nas ações de controle. A primeira diz respeito a generalidade e amplitude de suas funções. O Poder judiciário, a Defensoria pública e o Ministério Público possuem capítulos específicos no texto constitucional, o que imputa aos seus membros uma série de funções e prerrogativas que não podem ser contrariadas pelas normas inferiores. Ou seja, enquanto a imensa maioria das categorias profissionais tem seus regramentos jurídicos estabelecidos por leis ordinárias, no caso de magistrados, promotores e defensores públicos o regramento parte do próprio texto constitucional, o que redunda em menor campo de atuação do legislador ordinário.

A segunda hipótese tem relação com o "know how" que estas organizações possuem nos seus quadros. Por estarem diretamente ligadas ao métier jurídico é comum que haja um maior acompanhamento das matérias legislativas em andamento e, consequentemente, maiores as possibilidades de serem encontradas divergências entre as novas normas sancionadas e a constituição. Ademais, o quadro retrata um pensamento remoto mas ainda presente de que "o direito é para juristas", criando-se uma espécie de "elite intelectual" entre os detentores de conhecimento técnico e os demais profissionais.

\footnotetext{
${ }^{21}$ [ADPF 264 AgR, rel. min. Dias Toffoli, j. 18-12-2014, P, DJE de 25-2-2015.] Não custa lembrar que essa regra não se aplica à $\mathrm{OAB}$, que além de ser diretamente citada como legitimada pelo Art. 103, VII, CF/88, é, segundo entendimento do STF, uma entidade "sui generis" haja vista seu relevante papel na defesa da ordem democrática e dos direitos fundamentais.
}

${ }^{22}$ [ADI 4.224 AgR, rel. min. Dias Toffoli, j. 1º-8-2011, P, DJE de 8-9-2011.]

${ }^{23}$ [ADI 3.617 AgR, rel. min. Cezar Peluso, j. 25-5-2011, P, DJE de 1º-7-2011.]

${ }^{24}$ (ADI 894-MC, rel. min. Néri da Silveira, julgamento em 18-11-1993, Plenário, DJ de 20-4-1995.) 


\section{CONSIDERAÇÕES FINAIS}

Por muito tempo os chamados "operadores do direito" atuaram quase que com exclusividade na interpretação e conformação do texto constitucional, o que reduzia substancialmente a participação de setores externos ao meio jurídico nesse processo. Com a consolidação do constitucionalismo como fundamento moral da ordem jurídica e democrática essa limitação passou a ser percebida negativamente, apontando-se um déficit de legitimidade na atuação do Poder Judiciário.

A Constituição de 1988 não apenas consolidou a transição democrática no Brasil como preocupou-se em positivar regras que ampliassem efetivamente o papel dos cidadãos na tomada de decisão dos assuntos do Estado. No campo político essa mudança se deu através da participação popular nas decisões do mérito administrativo - como nos conselhos e consultas públicas. Já no campo jurídico a pluralização do debate encontrou maiores resistências, especialmente em razão do tradicional insulamento técnico-burocrático próprio do meio.

As modernas compreensões sobre democracia e cidadania, no entanto, vêm consolidando uma maior participação popular em assunto outrora restritos ao meio jurídico, o que fortalece a tese segundo a qual "todo aquele que vive uma constituição é seu autentico intérprete". No artigo verificou-se como esse processo de transição se deu em relação aos legitimados a proporem as Ações Diretas de Inconstitucionalidade - que passou de uma legitimidade exclusiva do Procurador-Geral da República para um amplo rol orientado por critérios federalistas, técnico-jurídicos, político-partidários e pluralistas.

Demonstra-se que o instrumento processual da ADI é de grande valia, tanto para fins de conformação das normas à melhor interpretação da constituição, quanto para expurgar do sistema jurídico aquelas que lhe contrariem. Assim, a análise do quantitativo de ADI's propostas por cada legitimado é um objeto de estudo válido para verificar-se o grau de amadurecimento da democracia brasileira.

No mérito, identifica-se que, com exceção dos governadores de estado, os legitimados políticos fazem pouco uso do instrumento processual; o que pode ser explicado tanto pela sua participação ativa no processo de inovação da ordem jurídica, quanto por eventuais divergências político-ideológicas nas Mesas Legislativas. Os representantes técnicos, OAB e PGR, possuem atuação constante propondo inconstitucionalidade de leis, havendo ou não relação com as respectivas categorias profissionais.

Os partidos políticos também fazem uso constante do instrumento processual, com destaque numérico para aqueles que não sofreram fusões nas últimas décadas (PT e PDT). Conforme apontado, a atuação dos partidos não fica limitada ao filtro da pertinência temática, 
o que possibilita que a Corte Constitucional torne-se uma nova arena de discussões ideológicas, desde que fundamentadas sob o prisma jurídico.

Por fim as confederações sindicais e entidades de classes configuram o mais alto grau de pluralismo entre os legitimados. A jurisprudência do STF vem se caracterizando bastante restritiva para tais entidades, estabelecendo além do filtro temático, requisitos que por vezes exclui determinadas organizações classistas do processo de controle constitucional. A análise das dez entidades com maior número de proposições demonstra que ainda há um claro protagonismo de associações de servidores públicos do meio jurídico e policial. Noutra via, grande organizações patronais também marcam presença com consideráveis números de ADI's propostas.

Os avanços oriundos da Constituição Cidadã são inegáveis quando se busca evoluir de uma sociedade "fechada" para "aberta" de intérpretes constitucionais. A ampliação do rol de legitimados a propor ações de controle concentrado é exemplo disso, na medida em que abre espaço para atores que não atuam diretamente no meio jurídico, mas que dispõe de informações e visões de mundo que podem colaborar decisivamente na decisão da Corte Constitucional.

\section{Referências}

AVRITZER, Leonardo; MARONA, Marjorie Corrêa Judicialização da política no Brasil: ver além do constitucionalismo liberal para ver melhor. Rev. Bras. Ciênc. Polít., Dez 2014, no.15, p.69-94

BOTELHO, Marcos César. Democracia e jurisdição: a legitimidade da jurisdição constitucional na democracia procedimental de Jürgen Habermas. Direito Público. Porto Alegre, ano 5, n.19, p. 218-233, jan./fev. 2008.

BRASIL. Lei $n^{o} 221$, de 20 de novembro de 1894. Completa a organisação da Justiça Federal da Republica. Acesso em: < http://www.planalto.gov.br/CCivil_03/leis/18511900/L0221.htm> Acesso em 1\%/07/2016

Constituição Federal (1946). Constituição dos Estados Unidos do Brasil. Disponível em: < https://www.planalto.gov.br/ccivil_03/Constituicao/Constituicao46.htm> Acesso em: $1 \% / 07 / 2017$

. Constituição Federal (1967). Constituição da República Federativa do Brasil. Disponível em: http://www.planalto.gov.br/CCivil_03/Constituicao/Constituicao67.htm Acesso em 1\% $\%$ /2017

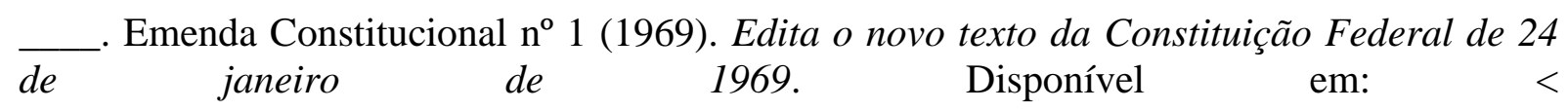


https://www.planalto.gov.br/ccivil_03/Constituicao/Emendas/Emc_anterior1988/emc0169.htm> Acesso em: 1\%07/2017

. Constituição Federal (1988). Constituição da República Federativa do Brasil. Disponível em: <http://www.planalto.gov.br/ccivil_03/Constituicao/ConstituiçaoCompilado. $\underline{\mathrm{htm}}>$. Acesso em: 1\%/07/2017

Lei $n^{\circ} 9.868$ de 10 de novembro de 1999. Dispõe sobre o processo e julgamento da ação direta de inconstitucionalidade e da ação declaratória de constitucionalidade perante o Supremo Tribunal Federal. Disponível em: <http://www.planalto.gov.br/ccivil_03/leis/L9868.htm> Acesso em 30/06/2017

CRUZ, Álvaro Ricardo de Souza. Jurisdição Constitucional Democrática. Belo Horizonte: Del Rey, 2004

CITTADINO, Gisele. Pluralismo, Direito e Justiça Distributiva - elementos da filosofia constitucional contemporânea. Rio de Janeiro: Lumen Juris 2000.

HÄBERLE, Peter. Hermenêutica Constitucional: a sociedade aberta dos intérpretes da Constituição - contribuição para a interpretação pluralista e 'procedimental' da Constituição. Trad. Gilmar Ferreira Mendes. Porto Alegre: Fabris, 1997

JUCÁ, Roberta Laena Costa. Pensar, Fortaleza, p. 181-186, abr. 2007. Edição Especial.

LIMA, Anderson Rodrigo Andrade de; ODORISSI, Luiza Ferreira. Interpretação Aberta da Constituição: aplicabilidade da obra de Peter Häberle ao Direito Brasileiro. Disponível em: http://sites.fadisma.com.br/entrementes/anais/wp-content/uploads/2015/08/interpretacaoaberta-da-constituicao_aplicabilidade-da-obra-de-peter-haberle-ao-direito-brasileiro.pdf. Acesso em: 30/07/2017

MENDES, Gilmar Ferreira; COELHO, Inocêncio Mártires; BRANCO, Paulo Gustavo Gonet. Hermenêutica Constitucional e Direitos Fundamentais. Brasília: Brasília Jurídica, 2000.

MORAES, Alexandre de. Direito Constitucional - 32º ed. São Paulo: Atlas, 2016

PAULA, Jônatas Luiz Moreira de. Democracia e Jurisdição. Curitiba: JM Editora e Livraria Jurídica. 2014, $221 \mathrm{p}$. 